\title{
The potential breeding value of snow clover (Trifolium pratense ssp. nivale (W.D.J. Koch) Arcang.) and red clover (Trifolium pratense ssp. sativum) hybrids
}

\author{
Galina Naydenova ${ }^{1} \&$ Viliana Vasileva ${ }^{2}$ \\ ${ }^{1}$ Experimental Station on Soybean, 61 Ruski Blv, 5200 Pavlikeni, Bulgaria; gmvg@abv.bg. \\ ${ }^{2}$ Institute of Forage Crops, 89 Vladimir Vazov Street, 5800 Pleven, Bulgaria.
}

Naydenova, G. \& Vasileva, V. (2019): The potential breeding value of snow clover (Trifolium pratense ssp. nivale (W.D.J. Koch) Arcang.) and red clover (Trifolium pratense ssp. sativum) hybrids. - Thaiszia - J. Bot. 29 (2): 217-224

Abstract: Eight red clover subspecies are registered in Europe but it can be considered that the high genetic diversity and local genetic adaptation existing at a subspecies level is unused. The experiment aimed at studying agronomical traits of the hybrids obtained from crosses of wild subspecies of Trifolium pratense - snow clover (Trifolium pratense ssp. nivale (W.D.J. Koch) Arcang.) and cultivated red clover (Trifolium pratense ssp. sativum). Under field conditions, two snow clover half-sib families $-F_{1}$ generation of crossbreeding were selected and compared to the paternal variety Nika 11 for three years. According to results, the size, habit of growth as well as dry matter productivity at spring growth of the $F_{1}$ hybrids were similar to the cultivated red clover. In summer regrowth, they were less productive. In terms of a type and rate of development the hybrids were similar to snow clover. From morphological point of view, the families proved of interest with its abundant leafiness, which renders them suitable for breeding in pasture direction. The hybrids are characterized by an icreased number of seeds per inflorescence and seed yield. The open-pollinated seeds of families were used for the formation of a population that represented the $F_{2}$ generation progenies. The phenotypic variation in the first vegetation of $F_{2}$ generation was high for plant flower colour, growth habit, and degree of pubescence. It can be considered that this population contains a high genetic variation and is suitable for development of complex hybrid breeding populations.

Keywords: intersubspecific hybrids, morphological traits, red clover, productivity, snow clover. 


\section{Introduction}

Red clover (Trifolium pratense L.) is the most commonly used legume species for the establishment of a temporary meadow and grazing grasslands in foothill and mountain areas of Balkan Peninsula (Mihovski et al. 2011; Bozhanska 2017; Bozhanska et al. 2018). Red clover breeding for these conditions is aimed at longevity, summer and aftermath productivity, grazing tolerance, forage quality, and seed yield. The possibilities of using interspecific crosses of Trifolium pratense with wild clovers as a bridge to introduce characteristics associated mainly with longevity were described (Abberton 2007). Nevertheless, it should be mentioned that there (as far as we know) are no practically spread of varieties of red clover except for the new Czech variety Pramedi (Dluhošová et al. 2016), developed through interspecific hybridization. At the same time, eight red clover subspecies are registered in Europe (Lopez Poveda 2012), but the high genetic diversity and local genetic adaptation existing at a subspecies level are unused in breeding. One of these subspecies is snow clover (Trifolium pratense ssp. nivale (W.D.J. Koch) Arcang.), which is spread on dry meadows in the alpine and sub alpine areas of Central and Southern Europe. The snow clover has biological and morphological characteristics of interest in the breeding of red clover, namely - prostrate and lower growth habit linked to tolerance to grazing or drought environment, slower rate of growth and thus greater longevity, strong pubescence with no glandular trichomes - micro morphological characteristic, linked to tolerance to low humidity, high light intensity and temperatures (Naydenova \& Georgiev 2013). So far, the snow clover has been studied as a site-specific legume in programs for the conservation of biodiversity and the restoration of degraded ecosystems (Romani et al. 2006), also as a new source of natural isoflavones with a different concentration pattern than in red clover (Tava et al. 2015).

Up to now, the intraspecific hybridization with the wild-growing subspecies of legumes has been used most successfully in alfalfa (Bingham et al. 2013; Milić et al. 2016). Intersubspecific sativa by falcata alfalfa (Medicago sativa L.) hybrids offer a means of improving alfalfa dry-matter yields (Riday \& Brummer 2004).

The present work aimed at testing some morphological characteristics, forage and seed productivity of hybrids obtained by crosses of two snow clover (Trifolium pratense ssp. nivale (W.D.J. Koch) Arcang.) subspecies and red clover (Trifolium pratense ssp. sativum).

\section{Material and methods}

\section{Cross and cultivation of subspecies}

The hybrids were created by spontaneous crosses between plants originated from a snow clover germplasm accessions (female parent) and the Bulgarian diploid earlymaturing red clover variety Nika 11 (male parent). The plants were grown in the field of the Experimental station of soybean, Pavlikeni, Bulgaria (latitude 4324' N; longitude 2532' E; altitude - $144 \mathrm{~m}$ ) in the 2012-2014 period. Soil type was leached chernozem and no fertilization was applied. In the third 
growing season, during the second cut close to the snow clover plants were placed flowering plants of Nika variety soaked in water. All plants were covered by canvas box to ensure open pollination.

Seeds produced on individual snow clover plants were harvested separately. The $F_{1}$ half-sib families, along with the paternal component, were sown in $2 \mathrm{~m}$ long single row with $0.50 \mathrm{~m}$ spacing between the rows and sowing rate of 1000 seeds per row. Randomized block design with two replications during spring 2015 was used.

The following traits were evaluated: type of development, plant height, internode number, number of branches per stem, leaf-to-stem ratio, stems and inflorescences in dry matter (in the first cut of second vegetation year), number of flower heads per stem, number of seeds per inflorescence, seed weight (in the second cut of second vegetation year), dry matter yield (per cuts from first to third vegetation year), seed yield. The morphological traits were measured in 10 plants of each row at the budding to early flowering stage. In the second cut of second vegetation, the rows were split into two parts for simultaneous monitoring of forage and seed productivity.

Equal amount of seed from the two families was mixed in order to trace hybrid progeny in $F_{2}$ generations. The formed polycross population was sown in the same nursery (in the spring in 2017). The following characteristics of hybrid plants were assessed in first vegetation year: type of development, habit of growth, plant flower colour.

\section{Statistical analysis}

Experimental data were statistically processed using Duncan's Multiply Range Test and Stat graphics Plus for Windows software package (Nau 2005).

\section{Results}

Two half-sib families - $F_{1}$ generation were selected and compared to the paternal variety. All $\mathrm{F}_{1}$ plants obtained by cross a snow clover (Trifolium pratense ssp. nivale) with red clover (Trifolium pratense ssp. sativum) cultivar Nika 11 had pink flowers, which differed from maternal genotypes that are white-blossoming (Fig. 1, 2). Their stems were characterized by a strong pubescence, typical of the snow clover, unlike the paternal variety, which has a low degree of pubescence with nonglandular trichomes. The leaves had leaf marks, which are inherent in the paternal component. Size and habit of growth of the $F_{1}$ hybrids were similar to the paternal genotype - cultivated red clover.

In terms of biological characteristics - type and rate of development hybrids were similar to snow clover. In the year of sowing, none of the $F_{1}$ plants formed any generative stems, and they wintered at the stage of the leaf rosette. They also have a slower rate of spring growing (with 9-10 days) than Nika 11.

During the second vegetation year, when the crop reached full development, the families exceeded with non-significant differences Nika 11 in dry matter yield at spring cut (Tab. 1). In summer regrowth, they were less productive. Also, compared to the paternal variety, they formed lower generative stems, with a 

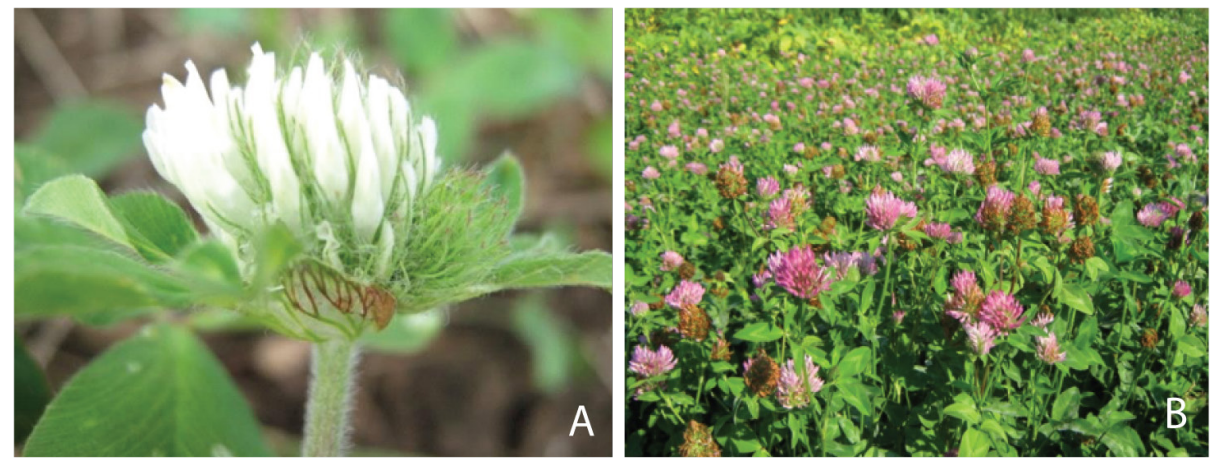

Fig. 1. (A) Snow clover (Trifolium pratense ssp. nivale) - maternal plant, (B) red clover (Trifolium pratense ssp. sativum) cultivar Nika 11 - paternal plants

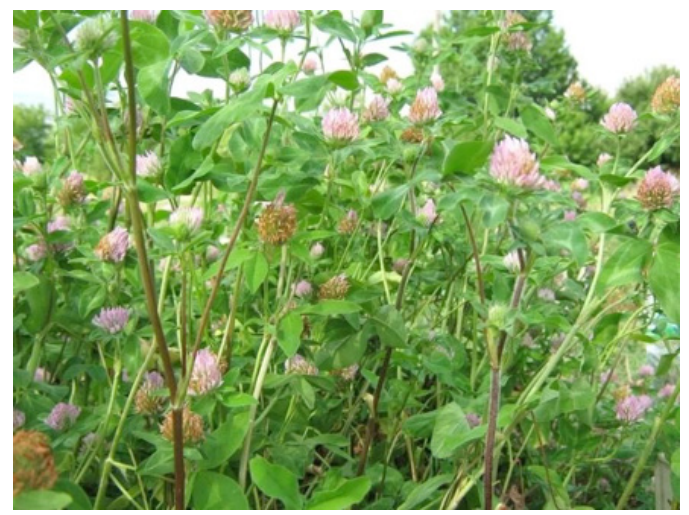

Fig. 2. $F_{1}$ plants obtained by cross a snow clover ( $T$. pratense ssp. nivale) with red clover ( $T$. pratense ssp. sativum) in second vegetation year

smaller number of stem internodes $(P<0.05)$. Plants of the snow clover families $-F_{1}$ hybrids had higher leafiness and correspondingly higher values of leaf/stem ratio. Also, in second vegetation among the investigated families and cultivated red clover, there were no significant differences in the number of branches per stem and number of inflorescences per stem. A significantly higher number of seeds per inflorescence were found in the hybrid family HSF 14 compared to the HSF 13. The advantage of this family to $n$ the paternal variety Nika 11 is nonsignificant. The mass of 1000 seeds of HSF 14 has lower values than in HSF 13 and cultivated subspecies. Snow clover family 13 had $39.8 \%(P<0.05)$ increases in seed yield in compare to cultivated paternal genotype. Seed productivity of the other family non-significantly differs from Nika 11. While seeds of paternal variety Nika 11 range in colour from light brown to purple, the seeds of hybrids were predominantly yellow. In third vegetation, dry matter yield by cuts nonsignificantly differed between snow clover family 13 and cultivated red clover. 
The other family - 14 had significantly lower productivity during spring growth and late-summer regrowth.

The open pollinated seeds of the two families were used for the formation of a population that represented the $F_{2}$ generation progenies. In first vegetation, phenotypic variation was greater in the $F_{2}$ generation for plant flower colour, growth habit and degree of pubescence, compared to parental generation (Fig. $3 a-f)$. Of the 33 plants observed in the population, five plants produced white flower heads (Fig. 3a, d, f), five pale pink (Fig. 3b), and three dark pink (Fig. $3 c)$. The remaining 21 plants have developed only a leaf rosette in the year of sowing. The blossoming plants had a semi-prostrate (Fig. 3c) and semi-erect growth habit (Fig. 3a). All plants of the $F_{2}$ generation had a leaf marker.

Tab. 1. Dry matter yield (DMY), seed yield and values of its determining elements in two $F_{1}$ half-sib families obtained by cross a snow clover (Trifolium pratense ssp. nivale) with red clover (Trifolium pratense ssp. sativum) and Nika 11 variety.

\begin{tabular}{|c|c|c|c|c|}
\hline & $\begin{array}{c}F_{1}- \\
\text { HSF13 }\end{array}$ & $\begin{array}{c}F_{1}- \\
\text { HSF14 }\end{array}$ & $\begin{array}{c}\text { var. Nika } \\
11\end{array}$ & LSD $_{0,05}$ \\
\hline DMY First vegetation I cut (kg. $\left.\mathrm{m}^{-1}\right)$ & - & - & 0,422 & \\
\hline DMY Second vegetation I cut (kg. $\left.\mathrm{m}^{-1}\right)$ & $0,693^{\text {ns }}$ & $0,684^{\mathrm{ns}}$ & $0,669^{\text {ns }}$ & 0,037 \\
\hline DMY Second vegetation II cut $\left(\mathrm{kg} \cdot \mathrm{m}^{-1}\right)$ & $0,468^{b}$ & $0,526^{b}$ & $0,662^{\mathrm{a}}$ & 0,114 \\
\hline DMY Third vegetation I cut (kg.m $\left.{ }^{-1}\right)$ & $0,076^{a}$ & $0,064^{b}$ & $0,086^{a}$ & 0,011 \\
\hline DMY Third vegetation II cut $\left(\mathrm{kg} \cdot \mathrm{m}^{-1}\right)$ & $0,116^{\mathrm{ns}}$ & $0,104^{\mathrm{ns}}$ & $0,126^{\text {ns }}$ & 0,042 \\
\hline DMY Third vegetation III cut $\left(\mathrm{kg} \cdot \mathrm{m}^{-1}\right)$ & $0,064^{a}$ & $0,038^{b}$ & $0,076^{\mathrm{a}}$ & 0,023 \\
\hline Seed yield $\left(\mathrm{g} \cdot \mathrm{m}^{-1}\right)$ & $13,7^{\mathrm{a}}$ & $11,0^{\mathrm{b}}$ & $9,8^{b}$ & 1,4 \\
\hline \multicolumn{5}{|l|}{ Structural elements } \\
\hline Plant height (mm) & $566^{b}$ & $612^{b}$ & $706^{a}$ & 70 \\
\hline Internode number & $5,1^{b}$ & $5,5^{b}$ & $6,5^{a}$ & 0,4 \\
\hline $\mathrm{Nb}$ of branches per stem & $2,8^{\text {ns }}$ & $2,1^{\text {ns }}$ & $2,4^{\mathrm{ns}}$ & 0,8 \\
\hline Leaves vs. stems ratio & 0,45 & 0,51 & 0,32 & \\
\hline $\mathrm{Nb}$ of inflorescences per stem & $4,2^{\text {ns }}$ & $4,0^{\text {ns }}$ & $4,5^{\mathrm{ns}}$ & 1,5 \\
\hline $\mathrm{Nb}$ of seeds per inflorescence & $50,4^{b}$ & $64,1^{\text {a }}$ & $55,7^{\mathrm{ab}}$ & 12,5 \\
\hline Mass of 1000 seeds (g) & 1,40 & 1,22 & 1,38 & \\
\hline
\end{tabular}

Mean values followed by same letters do not differ significantly at $\mathrm{P}<0.05$

\section{Discussion}

According to the results presented, snow clover can be successfully used in recombination breeding of cultivated red clover. The hybrids obtained from crosses of snow clover (Trifolium pratense ssp. nivale) as female parent and red clover (Trifolium pratense ssp. sativum) are characterized by great leafiness of stems, lower and flatter growth habit than red clover, fairly good summer productivity, and raised number of seeds per inflorescence (for a hybrid population HSF 14) and seed yield (for a hybrid population HSF 13) compared to red clover. The hybrids produced higher biomass yield through the spring growth of the first post-establishment year, compared to red clover but lower in the 

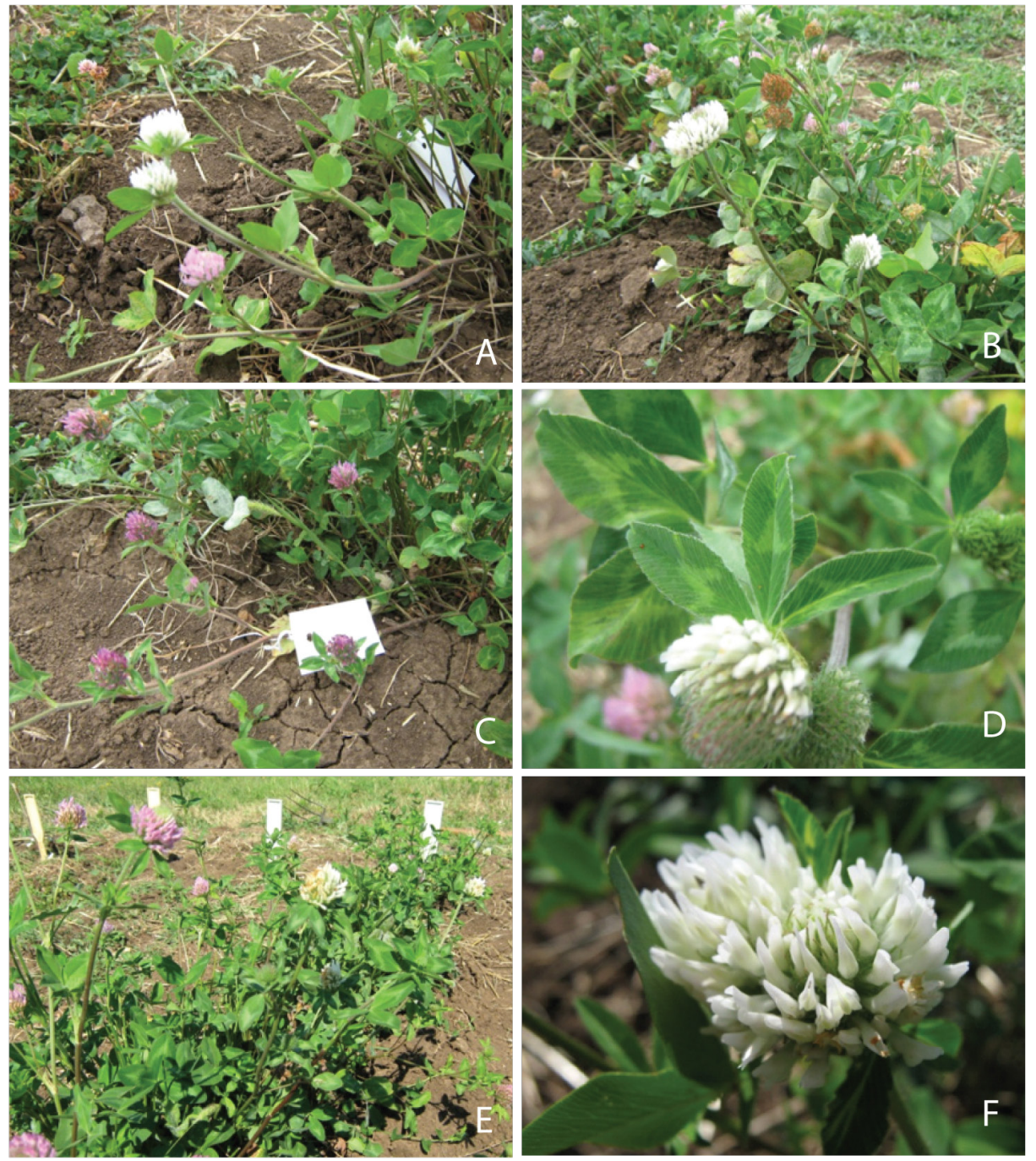

Fig. 3. Morphological variation in $F_{2}$ generation, first vegetation of cross a snow clover ( $T$. pratense ssp. nivale) with red clover (T. pratense ssp. sativum). (A) white flower heads and semierect growth habit; (B) pale pink flower heads; (C) dark pink flower heads and semi-prostrate growth habit; (D) white flower heads; $(E) F_{2}$ generation, first vegetation; (F) white flower heads.

subsequent year. Similar results have been obtained for intersubspecific sativa by falcata alfalfa (Medicago sativa L.) hybrids (Riday \& Brummer 2006).

In the aspect of using red clover for grazing, the breeding for great leafiness proves to be an important breeding aim and can be considered as breeding 
for productivity, since great leafiness of stems provides higher palatability and intake potential of forage (Poli 1998). The higher leafiness of the resulting hybrid material can be considered as a characteristic associated with a breeding potential in pasture direction.

The durability of legumes in pasture swards depends predominantly on selfmaintenance mechanisms, one of which is self-resowing. The low persistence of red clover is associated with low seed yield potential (Ford \& Barrett 2011). The high and ecologically stable seed productivity maintains a seed bank and ensures the natural reseeding of the species. From this perspective, the high seed productivity of our hybrids can also connect to pasture potential. Nika 11 variety is characterized by high seed productivity (Nedělník et al. 2016). The family 13 that surpasses it in seed production is a suitable genetic resource in red clover breeding for seed yield. In addition, the seeds of the hybrids are predominantly yellow, which, according to Atis et al. (2011), can be considered as an indicator of the quality of red clover seeds. Yellow-colored seeds of red clover had a higher germination rate than other colors (Costa et al. 2019).

$F_{2}$ population has heterogeneous biotype composition. Biotype segregation has key significance to the sustainability of the population in the sward (Novoselova 1981). This result could be considered as an indicator of the adaptive potential of the hereditary material created by investigated intraspecific hybridization. The $F_{2}$ generation contains a high morphological, respectively genetic variation and is suitable for developing of complex hybrid (synthetic) breeding populations, which can be utilized in recurrent phenotype breeding scheme aimed at creating a pasture variety well adapted to the foothill and mountain areas of Balkan Peninsula.

\section{Conclusion}

The hybridization of cultivated red clover with wild subspecies of snow clover was considered as a valuable source of variability in the breeding of red clover for both, increased seed production and suitability for grazing.

\section{References}

Abberton M. T. (2007): Interspecific hybridization in the genus Trifolium. - PI. Breed. (New York) 126(4): 337-342. https://doi.org/10.1111/j.1439-0523.2007.01374.x

Atis I., Atak M., Can E. \& Mavi K. (2011): Seed coat color effects on seed quality and salt tolerance of red clover (Trifolium pratense). - Int. J. Agric. Biol. 13(3): 363-368.

Bingham E., Armour D., Irwin J. (2013): The hybridization barrier between herbaceous Medicago sativa and woody $M$. arborea is weakened by selection of seed parents. - Plants 2(2): 343-353. doi:10.3390/plants2020343

Bozhanska T. (2017): Study on perennial legume-grass mixtures in the conditions of the Central Balkan mountain. - Banats J. Biotechnol. 8(15): 34-42. doi:10.7904/20684738-VIII(15)-34

Bozhanska T., Churkova B., Mihova T. (2018): Basic chemical composition and energy nutritional value of fodder biomass from artificial ecosystems. - Biotechnol. Anim. Husb. 34(3): 355-367. https://doi.org/10.2298/BAH1803355B 
Costa A. S., Dias L. S. \& Dias A. S. (2019): Imbibition, Germination, and Early Seedling Growth Responses of Light Purple and Yellow Seeds of Red Clover to Distilled Water, Sodium Chloride, and Nutrient Solution. - Sci. 1(1), 10. https://doi.org/10.3390/ sci1010010.v1

Dluhošová J., Řepková J., Jakešová H., Nedělník J. (2016): Impact of interspecific hybridization of $T$. pratense $\times T$. medium and backcrossing on genetic variability of progeny. - Czech J. Genet. PI. Breed. 52(4): 125-131. doi: 10.17221/115/2016-CJGPB

Ford J. L. \& Barrett B. A. (2011): Improving red clover persistence under grazing. - In: Proceedings of the New Zealand Grassland Association 73: 119-124.

Lopez Poveda L. (2012): Trifolium pratense. The IUCN Red List of Threatened Species 2012: e.T174713A20156449.

Mihovski T., Chourcova B., Mitev D. (2011): Comparative study of different varieties of red clover in Bulgarian conditions. - J. Agr. Sci. Tech. 3(2): 130-133.

Milić D., Taški-Ajduković K., NagI N., Atlagić J., Karagić Đ. (2016): Utilization of M. sativa ssp. caerulea $\times M$. sativa ssp. sativa hybridization in improvement of alfalfa aluminium tolerance. - Plant Genet. Resour-C 16(1): 68-73. https://doi. org/10.1017/S1479262116000447

Nau R. (2005): Statgraphics version 5: overview \& tutorial guide. - Fuqua School of Business. - Duke University.

Naydenova G. \& Georgiev G. (2013): Physiological function of non-glandular trichomes in red clover (Trifolium pratense L.). - J. Agric. Sci. (Belgrade) 58(3): 217-222. DOI: 10.2298/JAS1303217N

Nedělník J., Knotová D., Pelikán J., Vymyslický T., Mihovski Ts., Naydenova G. (2016): Comparing yield potential of Czech and Bulgarian red clover varieties. - J. Mount. Agricult. Balkans (Troyan) 19(1): 38-45.

Novoselova A. (1981): Reserves of increasing the effectiveness of breeding red clover. Selektsiia i semenovodstvo. - Moskow.

Poli C. H. E. C. (1998): Effects of physical and biochemical characteristics of contrasting legume swards on selective behavior of grazing cattle. PhD Thesis, College of Sciences, Massey University. - Palmerston North. New Zealand.

Riday H. \& Brummer E. C. (2004): Performance of intersubspecific alfalfa hybrids in sward versus space planted plots. - Euphytica 138(2): 107-112. https://doi.org/10.1023/ B:EUPH.0000046755.07566.c3

Riday H. \& Brummer E. C. (2006): Persistence and yield stability of intersubspecific alfalfa hybrids. - Crop Sci. 46(3): 1058-1063. doi:10.2135/cropsci2005.0272

Romani M., Pecetti L., Paolett R., De Rosa L., Franzini E., \& Piano E. (2006): Evaluation of snow clover (Trifolium pratense subsp. nivale) germplasm native to the Retic Alps, for the restoration of degraded landscapes at high altitude. - In: Proceedings of the $50^{\text {th }}$ Italian Society of Agricultural Genetics Annual Congress, Ischia, 10/14 September 2006. Poster abstract A. 28.

Tava A., Pecio Ł., Stochmal A., Pecetti L. (2015): Clovamide and Flavonoids from Leaves of Trifolium pratense and T. pratense subsp. nivale Grown in Italy. - Nat. Prod. Commun. 10(6): 933-936. https://doi.org/10.1177\%2F1934578X1501000635 